\title{
The Mapping of Sharia Economic Dispute Decisions in Religious Courts
}

\author{
Ridwan ${ }^{1}$, Muhammad Fuad Zain², Bani Syarif Maula ${ }^{3}$ \\ \{ridwan@iainpurwokerto.ac.id ${ }^{1}$ \} \\ Faculty of Sharia, State Institut for Islamic Studies, Purwokerto, 53126, Indonesia ${ }^{1,2,3}$
}

\begin{abstract}
This article analyzes Law No. 3 of 2006, which has extended competence to the Religious Courts in the resolution of Sharia economic disputes. The research data came from the results of the judge's interview on the court's decision regarding the validity and competence of the judge. The author finds that in judicial legal considerations in case No. 2074/Pdt.G/2017/PA.Pwt gave rise to the theory that the restructuring of murabaha contracts should not be carried out on debtors who are unable to pay installments by the agreement and auction off collateral items that are correct and not deeds against the law. While case No. 2449/Pdt.G/2018/PA.Pwt in the musharaka contract reject the potential loss by referring to Fatwa DSN No. 43/DSN-MUI/VIII/2014, which states that the amount of compensation in the participation contract is the value of the real loss that must be experienced in a transaction. Legal discovery using the material and formal legal basis with the method of interpretation of the legislation and restrictive method by limiting or narrowing the interpretation of the legislation in the framework of prudence so as not to make a mistake in making a decision.
\end{abstract}

Keywords: Religious Courts, Dispute, Islamic Economics, Interpretation, Restrictive

\section{Introduction}

The genesis of Law Number 3 of 2006 about Amendments to Law Number 7 of 1989 about Religious Courts has brought major changes to the Religious Courts in Indonesia. The fundamental change lies in Article 49 point (i) which states that the Religious Court has the duty and authority to examine, decide upon and settle cases at the first level between people who are Muslim in the areas of marriage, inheritance, wills, grants, endowments, tithe, donation, alms, and sharia economics [1]. Where previously, Law Number 7 of 1989 Concerning Religious Courts in article 49 only on cases marriage, inheritance, wills, grants, endowments, tithe, donation, and alms [2].

The issue of the incompetence of the Religious Courts also arose, among others, related to the ability to handle sharia economic dispute cases? There are those who still doubt the ability of Religious Court judges in examining and judging Islamic banking [3]. The existence of stereotypes and stigmatization was also justified by Topo Santoso; according to him, the stereotype must be resisted by building trust and the right image by the Religious Courts themselves [1].

On the other hand, the polemic about the existence of the duties and authority of the National Sharia Abrasive Agency (BASYARNAS) began to narrow in resolving sharia economic disputes. With the existence of Law No. 3 of 2006 automatically, the duties and 
authority are in the Religious Courts [4]. What is meant by sharia economics is not only limited by resolving disputes in the banking sector, but also in other sharia economics fields, such as: sharia microfinance institutions; sharia insurance; sharia reinsurance: sharia mutual funds; sharia medium-term bonds and bonds; sharia securities; sharia financing; sharia pawnshop; pension funds for Islamic financial institutions; and sharia business. Sharia economic definitions in the sharia economic law compilation are businesses or activities carried out by individuals, groups of people, business entities that are legal entities, or not legal entities in order to meet commercial and non-commercial needs according to sharia principles [5]. Purwokerto Religious Court is one of the Religious Courts that has a duty as a law enforcement agency in Banyumas Regency, one of its competencies is to decide the sharia economic dispute. In this study, the authors focus on examining the results of judges' decisions on Islamic economic disputes. In this article, will discuss the fundamental differences between mudharaba and musharaka contracts, because both are the core problems of Islamic economic disputes.

\section{Method}

This type of research is field research; data is collected from the Purwokerto Religious Court by interviewing judges related to Sharia economic dispute decisions using a descriptiveanalytic approach by describing the problem through the collection, preparation, and analysis of data, and then assessing the research problem. In this study, the writer uses a normative approach by looking at law as a whole system covering legal principles, legal norms, and written and unwritten rules.

\section{Results and Discussion}

\subsection{Islamic banking in Indonesia}

Islamic Bank in Indonesia was born not apart from the history of Muamalat Bank (1992) using the principle of deposit, mudharaba. The investment of funds on Islamic Bank uses the principle of buying and selling, profit-sharing and rent. Banking in Indonesia is divided into two, namely Commercial Banks and Credit Banks, both Conventional (interest) and Islamic Bank (profit sharing), which synergize in supporting full mobilization of public funds to improve financing capabilities for national economic sectors. The majority of Indonesian people are Muslims (80\%), although the legal system is built on the basis of unity in diversity with the aim of unity and integrity [6].

With the enactment of Law No. 21 of 2008 concerning Sharia Banking, which was published on July 16, 2008, the development of the national Islamic banking industry increasingly has an adequate legal basis and will encourage its growth even faster. With its impressive progress in development, which has achieved an average asset growth of more than $65 \%$ per year in the last five years, it is hoped that the role of the Islamic banking industry in supporting the national economy will be even more significant.

However, it cannot be denied that Islamic economic growth was also colored by Islamic economic disputes, which were finally decided through Non-Litigation by BASYARNAS and Litigation by the Religious Courts. For example, in the Purwokerto Religious Court alone in 2018-2019, there were 13 economic disputes with five murabaha and eight musharaka cases. 
Islamic banks have two leading roles, namely, as a business entity and social agency. As a business entity, Islamic banks have several functions, namely as investment managers, investors, and services. As an investment manager, Islamic banks collect funds from investors/customers with the principle of deposit, mudaraba, or rent. As an investor, Islamic banks channel funds through investment activities with the principle of profit-sharing, buying and selling, or leasing. As a banking service provider, Islamic banks provide financial services, non-financial services, and agency services. Financial services include, but are not limited to the principles of agency, guarantee, money order, pawn, loan, exchange, and others nonfinancial services in the form of agency services with the principle of restricted mudharaba. Meanwhile, as a social body, Islamic banks have functioned as managers of social funds for the collection and distribution of tithe, donation, and alms, as well as the distribution of benevolent loans [6].

Islamic banks are banks with profit-sharing principles, which are the main foundation in all of their operations, both in the mobilization of funds and in the distribution of funds (in Islamic banking the distribution of funds is commonly referred to as financing). Therefore, the types of fundraising and financing provided to Islamic banks mainly use the profit sharing principle. In addition to the profit sharing principle, Islamic banks also have alternative fundraising and nonprofit financing. In raising funds, Islamic banks can also use the principles of agency, loan, or rent. In financing, Islamic banks can also use the principle of buying and selling and leasing. In addition, Islamic banks also provide various financial services such as agency, guarantee, money order, mortgage, loan, exchange, and rent.

The most dominant source of funds comes from the principle of restricted mudharaba which usually reaches more than 60 percent and takes the form of savings, time deposits, or bonds [6]. Pooling funds are then used in the distribution of funds in the form of financing with the principles of profit sharing, buying and selling, and rent. From the profit-sharing principle, the profit-sharing portion is obtained according to the initial agreement (profit sharing ratio) with each customer; from financing with the principle of buying and selling obtained profit margins; while from financing with the rental principle, it is obtained rental income. The entire income from the pooling fund is then collected between the bank and all customers who deposit, save, or invest their money in accordance with the initial agreement. The customer portion or third party rights will be distributed to the customer, while the bank's portion will be included in the income statement as the main operating income. Meanwhile, other income, such as from restricted mudharaba and financial services, are included in the income statement as other operating income.

In approximately 15 years, before the enactment of Law No.1 of 1974 about marriage until before Law No.7 of 1989 concerning Religious Courts, there is two developments journey of religious justice in Indonesia. First, the process of the birth of Law No. 1 of 1974 concerning Marriage with regulations implementing Government Regulations No. 9 of 1975, secondly the birth of Government Regulation No. 28 of 1977 regarding representation which has been renewed by Law No. 41 of 2004 concerning endowments [7]. The birth of Law No. 1 of 1974 concerning Marriage which applies to all Indonesian citizens on January 2, 1974 has largely met the demands of the Indonesian people. This demand has been echoed since the first Indonesian Youth Pledge in 1928, which was then put forward on other occasions, in the form of hopes of improving the position of women in marriage. This coveted improvement is mainly for the "original Indonesian" group who are Muslim, where their rights and obligations in marriage are not regulated in a written law. Indonesian original marriage laws of Islam that are listed in fiqh books, according to the Indonesian legal system cannot be classified in the category of written law, because it is not written in government regulations. 
The next step is the preparation of the religious court bill until its ratification in the DPR forum into Law No.7 of 1989 (29 December 1989) which is a typical phenomenon of the new order, and has happened in 1974, that when it concerns the core values of Islam, members of the DPR who are Muslims have the same position [8]. Although the Protestant and Catholic press vigorously opposed the religious court bill, the discussion proceeded smoothly without obstacles to passing it into Law No.7 of 1989. Ratification of Law No.7 of 1989 on Religious Courts, brought enormous changes to the position of religious justice, not only in its position as a judicial institution as part of implementing the same judicial power as other judicial institutions [9].

However, the ratification of giving full authority which is the main task of the religious court to resolve the cases of Muslims in Indonesia relating to family law. With the birth of the religious court law, the religious court has become independent in Indonesia in upholding the law based on Islamic law for those seeking justice in the religion of Islam relating to civil cases in the fields of marriage, inheritance, wills, grants, and endowments [8].

Thus, Muslims in Indonesia are required to submit their cases to the religious court, which is the authority of the religious court. After two years of enactment of Law No.7 of 1989 concerning Religious Courts, the Presidential Instruction No.1 of 1991 concerning the Compilation of Islamic Law (KHI) was stipulated to support the implementation of religious courts. Compilation of Islamic Law was not born suddenly but experienced an assessment and a process that was not short. Even in the realm of politics. This is done so that the religious court in carrying out its duties and authority has a definite territory and path. Because Law No. 1 of 1974 concerning Marriage does not yet include other Islamic civil cases that should be under the authority of the religious court, not only are the marital issues contained in the marriage law not yet detailed in the marriage matters. In-Law No.4 of 2004 concerning Judicial Power, as an amendment to Law No. 35 of 1999 concerning amendment to No.14 of 1970 concerning Judicial Power, it is explained that judicial power is exercised by courts in the environment of a) general court, b) religious court, c) military justice, and d) state administrative justice [10].

Religious court has are five duties and authorities, namely: 1) The function of the authority to judge, 2) Give information, considerations, and advice on Islamic law to government agencies, 3) Other authorities by or based on the law, 4) The authority of the religious high court hears the case on an appeal level and hears the relative dispute, 5) Has the duty to oversee the proceedings.

In principle, the power and authority of the religious court with other courts, be it the general court, state administrative court, or military court, are the same. However, the difference lies in the power of hearing or cases which become the authority of each court (absolute authority). We can exemplify the absolute authority possessed by religious courts as cases of Islamic justice seekers regarding civil matters such as marriage and inheritance; then these cases become the absolute authority of religious courts to receive, examine and decide on these cases.

As for those who are not Muslim, their case must be submitted to the state court to be settled. However, if cases of justice seekers who have a religion in Islam have been decided by the religious court, then the justice seeker does not accept the decision of the religious court, then it can appeal to a higher institution, the Religious High Court. 


\subsection{Sharia economic disputes}

\subsubsection{Overview of purwokerto religious court}

Purwokerto Religious Court is a court under the auspices of the Supreme Court located on Jl. Guerrilla No. 7 A Purwokerto with Accredited I A. PA Purwokerto is currently led by chairman Drs. H. Tahrir. With the birth of Law No. 3 of 2006 concerning Amendments to Law No. 7 of 1989 Concerning Religious Courts, PA Purwokerto has the task and authority to examine, decide upon and settle cases at the first level among people who are Muslim in the areas of marriage, inheritance, wills, grants, endowments, tithe, infaq, alms, and sharia economics.

The legal territory map of the Purwokerto Religious Court covers the entire area of the Banyumas Regency, which consists of 16 Districts and 178 Villages. The map of the jurisdiction covers Gumelar District, Lumbir District, Wangon District, Rawalo District, Jatilawang District, Ajibarang District, Pekuncen District, Baturraden District, Purwokerto Timur District, Kedungbanteng District, North Purwokerto District, Purwojati District, Purwokerto Selatan District, Purwokerto Barat District, Karanglewas District, and Cilongok District.

Religious Court Purwokerto has 13 judges, namely: (1) Drs. H. Tahrir, (2) Drs. Asnawi, S.H., M.H., (3) Drs. Nasirudin, M.H., (4) Drs. Sutejo, S.H., M.H., (5) Drs. H. Ace Ma'mun, M.H., (6) Drs. H. Risno, (7) Drs. H. Juhri, M.H., (8) Titi Prize M electives, S.H., (9) Drs. Mahasin, S.H., (10) Dra. Teti Himati, (11) Drs. Marwoto, S.H., M.S.I., (13) Drs. Asmuni Wahdar, M.S.i., (13) Nana, S.Ag. Of the 13 judges above, only three judges already possessed certificates of handling Sharia Economic Disputes namely Drs. H. Risno, Drs. Sutejo, S.H., M.H., Drs. H. Ace Ma'mun, M.H. [11]. The PA Purwokerto judge who has a mediator certificate is only one, Titi Prize M electi, S.H. In 2019 PA Purwokerto proposed in mediator certification training namely Drs. H. Juhri, M.H., and Nana, S.Ag. [11].

Data for 2018-2019 shows that the growth of cases concerning Islamic economic disputes has been developing (Table 1):

Table 1. Research data

\begin{tabular}{llllll}
\hline No & Year & \multicolumn{1}{c}{ Case Number } & Type of Agreement & $\begin{array}{c}\text { Length of } \\
\text { Court }\end{array}$ & Verdict \\
\hline $\mathbf{1}$ & 2019 & 2169/Pdt.G/2019/PA.Pwt & Murabaha & 17 days & Granted \\
$\mathbf{2}$ & 2019 & 0001/Pdt.G.S/2019/PA.Pwt & Murabaha & 16 days & Granted \\
$\mathbf{3}$ & 2019 & 0934/Pdt.G/2019/PA.Pwt & Murabaha & 164 days & In the judge \\
$\mathbf{4}$ & 2019 & 0531/Pdt.G/2019/PA.Pwt & Murabaha & 192 days & In the judge \\
$\mathbf{5}$ & 2019 & 0398/Pdt.G/2019/PA.Pwt & Murabaha & 155 days & Granted by Verstek \\
$\mathbf{6}$ & 2019 & 0336/Pdt.G/2019/PA.Pwt & Musharaka & 63 days & Granted \\
$\mathbf{7}$ & 2019 & 0276/Pdt.G/2019/PA.Pwt & Musharaka & 250 days & Granted \\
$\mathbf{8}$ & 2019 & 0192/Pdt.G/2019/PA.Pwt & Musharaka & 32 days & Peaceful \\
$\mathbf{9}$ & 2018 & 2795/Pdt.G/2018/PA.Pwt & Musharaka & 296 days & Appeal \\
$\mathbf{1 0}$ & 2018 & 2449/Pdt.G.S/2018/PA.Pwt & Musharaka & 36 days & Rejected \\
$\mathbf{1 1}$ & 2018 & 2450/Pdt.G.S/2018/PA.Pwt & Simple Suit & 42 days & Rejected \\
$\mathbf{1 2}$ & 2018 & 1491/Pdt.G/2018/PA.Pwt & Musharaka & 354 days & Peaceful \\
$\mathbf{1 3}$ & 2018 & 0217/Pdt.G/2018/PA.Pwt & Musharaka & 167 days & Rejected by Verstek \\
\hline
\end{tabular}




\subsubsection{Overview of case no. 2449 / Pdt.G.S / 2018 / PA.Pwt}

Case No. 2449 / Pdt.G.S / 2018 / PA.Pwt is an Islamic economic dispute related to defaults on community contracts between Islamic Banks as plaintiffs against their customers. In the dispute it states that:

- Plaintiffs and Defendants I and Defendants II agreed in a musharaka

- Contract on the Working Capital for the Construction of a Shophouse that funds Rp. 250 million consisting of Rp. 135 million from Sharia Banks (Plaintiffs) and Rp. 115 million from customers (Defendant I and Defendant II);

- The contract period is 4 months starting on February 21, 2017 and ending on June 21, 2019;

- Plaintiff and Defendant I and Defendant II agreed with the distribution of the ratio as follows: The Plaintiff received $54 \%$ while the Defendant $46 \%$ of the musharaka contract profit;

- Defendants I and Defendant II are bound by an agreement to return capital of Rp. 135 million and projected profit sharing of Rp. 9,452,000.

Then in reality after Defendant I and Defendant II had only returned the capital costs as much as Rp. 48,715,241, - so that the capital paid is Rp. 86,284,759, - and have not paid the profit sharing of Rp. 9,452,000,- so Defendant I and Defendant II have breached the contract (breach of contract). The total losses that have not been paid until September 2018 or for 15 months are as follows:

- $\quad$ Remaining the Capital: Rp. 86,284790.

- $\quad$ Projected profit-sharing that hasn't been paid for 15 months: Rp. 42,534,000.

- Total loss: Rp. 128,818,759.

- The contract includes a guarantee of 898 M2 and 1020 M2 of land which is an inseparable part of the musharaka contract.

- The judge's decision is granted

\subsubsection{Overview of Case No. 2074 / Pdt.G.S / 2018 / PA.Pwt}

Case Number 2074 / Pdt.G.S / 2018 / PA.Pwt is a Sharia Economic Dispute case regarding a default on the murabaha financing contract that occurred between the Sharia Bank as the plaintiff and its customers (Defendant I and Defendant II). In the dispute it states that:

- On May 28, 2015 the defendant received a working capital murabahah financing agreement with the following details:
a. Capital Financing
b. Margin
c. Duration of
: Rp. $350,000,000$.
d. Maturity
: Rp. 316,000,000.
e. Payment every month : Rp. 9,250,000.
f. Total Debt
: Rp. 666,000,000.

- Collateral in a murabahah financing agreement is a plot of land covering an area of 305 $\mathrm{m} 2$.

- Defendant experienced difficulties in payment so that the repayment period was extended to 103 months.

- Rescheduling of the contract with the following conditions:
a. Remaining Capital
: Rp. 269,250,000. 

b. Profit
: Rp. 243,150,000.
c. Duration of
: 103 Months
d. Total Debt
: Rp. 512,400,000.

- The remaining debt from the defendant
a. Unpaid capital
: Rp. 259,061,086.
b. Profit
: Rp. 233,949,925.
c. Total Debt
: Rp. 493,011,011.

- In the contract, the defendant included a plot of land covering an area of 305 M2.

- The judge's decision is granted

\section{Conclusion}

Legal considerations in deciding Sharia economic dispute cases in the Purwokerto Religious Court refer to formal and material law, whereas in case No. 2074 / Pdt.G / 2017 / PA.Pwt on murabahah contracts with the Kabul verdict for the whole so that the theory emerges that the restructuring of murabahah financing contracts should not or should not be done to debtors who clearly cannot afford to pay installments in accordance with the agreement and auction off goods in the form of a plot of land measuring $305 \mathrm{~m} 2$ is a righteous act and not an illegal act, so collateral is the plaintiff's right. Whereas in case No. 2449 / Pdt.G / 2018 / PA.Pwt on a musharaka contract with a ruling granting it to others and rejecting potential loss by referring to Fatwa DSN No. 43 / DSN-MUI / VIII / 2014 which states that the amount of compensation may not be added to the contract and must be based on the value of the real losses that must have been experienced in the transaction, while the definition of real costs are costs incurred in the context of collection of rights that should be paid by customers, litigation costs and other costs incurred as a result of the dispute resolution process (litigation).

\section{References}

[1] M. D. Hadad, "Majalah Peradilan Agama," Direktorat Jendral Badan Pengawas Peradilan Agama Mahkamah Agung RI, p. 3, 2014.

[2] B. Azheri, "Urgency of the establishment of a special court for the resolution of sharia economic dispute in the religious courts," J. Leg. Ethical Regul. Issues, vol. 21, no. 1, pp. 1-7, 2018.

[3] A. A. Yusuf, "Controversy of Islamic Law on The Distribution of Inheritance to the Heirs of Different Religion," Hunafa J. Stud. Islam., vol. 14, no. 2, pp. 377-403, 2017, doi: 10.24239/jsi.v14i2.490.377-403.

[4] R. T. Yulianti, "Sengketa Ekonomi Syari'ah (Antara Kompetensi Pengadilan Agama dan Badan Arbitrase Syari'ah)," al-Mawarid, vol. Edisi XVII, pp. 45-60, 2007.

[5] M. Agung, Kompilasi Hukum Ekonomi Syari’ah. 2008, p. Nomor 2 Tahun 2008.

[6] A. D. Yumanita, "Bank Syariah: Gambaran Umum," in Seri Kebanksentralan Bank Indonesia, Jakarta: Pusat Pendidikan dan Studi Kebanksentralan, 2005.

[7] A. Alfitri, "Whose Authority? Contesting and Negotiating the Idea of a Legitimate Interpretation of Islamic Law in Indonesia," Asian J. Comp. Law, vol. 10, pp. 191-212, Dec. 2015, doi: 10.1017/asjcl.2016.1.

[8] E. Gunawan, "Peranan Pengadilan Agama dalam Pembaruan Hukum Islam di Indonesia," SYARIAH J. Huk. dan Pemikir., vol. 16, no. 1, pp. 77-86, 2016. 
[9] R. A. \& M. R. Masse, "Islamic Banking Dispute Resolution in National Sharia Arbitration Board," in IOP Conference Series: Earth and Environmental Science, 2018, pp. 1-6, doi: 10.1088/17551315/175/1/012169.

[10] F. S. R. \& G. A. \& K. L. S. A. Roro, "The Characteristics of Sharia Compliance in the Settlement of Sharia Economic Disputes in Indonesia," in International Conference on Law, Governance and Globalization, 2017, pp. 113-126, doi: 10.2991/iclgg-17.2018.15.

[11] Risno, "Interview," Purwokerto, 2019. 